Vol. 1 No. 3 Desember 2021 e-ISSN : 2797-3344 P-ISSN : 2797-3336

\title{
PENERAPAN METODE DEMONSTRASI UNTUK MENINGKATKAN HASIL BELAJAR IPA PADA SISWA KELAS V SEMESTER GENAP SD NEGERI 3 MAMBEN LAUK KECAMATAN WANASABA TAHUN PELAJARAN 2020/2021
}

\author{
HADIJAH \\ SDN 3 Mamben Lauk, Wanasaba, Lombok Timur \\ hadijah.dijah@gmail.com
}

\begin{abstract}
ABSTRAK
Penelitian ini bertujuan untuk meningkatkan hasil belajar IPA siswa kelas V SD Negeri 3 Mamben Lauk dengan menerapkan metode Demonstrasi. Jenis penelitian ini adalah Penelitian Tindakan Kelas reflektif. Subjek penelitian ini adalah siswa kelas V SD Negeri 3 Mamben Lauk yang berjumlah 25 siswa, dikarenakan masa covid-19 peneliti mengambil subyek sebanyak 13 siswa. Desain penelitian yang digunakan adalah model dari Suharsimi Arikunto. Metode pengumpulan data yang digunakan dalam penelitian ini adalah: 1) perencanaan tindakan (planning), 2) pelaksanaan tindakan (acting), 3) observasi (observation), dan 4) refleksi (reflektion). Teknik analisis data yang digunakan adalah deskriptif kuantitatif. Berdasarkan data yang diperoleh dari hasil observasi baik terhadap tindakan guru dan siswa yang menggunakan lembar observasi dan data hasil belajar siswa yang diperoleh dengan menggunakan lembar tes, dilaksanakan setelah kegiatan belajar mengajar, dengan menngunakan Metode Demonstrasi secara bertahap mampu meningkatkan hasil belajar siswa di kelas V SD Negeri 3 Mamben Lauk. Peningkatan hasil belajar siswa ditunjukkan dengan meningkatnya nilai rata-rata hasil belajar siswa pada setiap tindakan. Pada tahap pra siklus, nilai rata-rata kelas yang diperoleh adalah 58,84, pada siklus I nilai rata-rata yang diperoleh adalah 66,15 dan siklus II sebesar 79,23 ini membuktikan bahwa setiap siklus mengalami peningkatan pada setiap tahap tindakan. Persentase ketuntasan klasikal juga mengalami peningkatan pada setiap tahap tindakan. Pada tahap pra tindakan persentase ketuntasan klasikal sebesar 38,46\%, siklus I sebesar $61,54 \%$, dan siklus II sebesar 92,3\%.
\end{abstract}

Kata Kunci: Inkuiri, metode demonstrasi, hasil belajar, IPA

ABSTRACT

This study aims to improve science learning outcomes for fifth grade students of SD Negeri 3 Mamben Lauk by applying the demonstration method. This type of research is reflective Classroom Action Research. The subjects of this study were the fifth grade students of SD Negeri 3 Mamben Lauk, totaling 25 students, due to the Covid-19 period the researchers took as many as 13 students as subjects. The research design used is the model of Suharsimi Arikunto. The data collection methods used in this research are: 1) action planning (planning), 2) action implementation (acting), 3) observation (observation), and 4) reflection (reflection). The data analysis technique used is descriptive quantitative. Based on the data obtained from the results of observations both on the actions of teachers and students who use observation sheets and student learning outcomes data obtained using test sheets, carried out after teaching and learning activities, using the Demonstration Method is gradually able to improve student learning outcomes in class V SD Negeri 3 Mamben Lauk. The increase in student learning outcomes is indicated by the increase in the average value of student learning outcomes in each action. In the pre-cycle stage, the average grade obtained was 58.84, in the first cycle the average value obtained was 66.15 and the second cycle was 79.23 . This proves that each cycle has increased at each stage of the action. The percentage of classical completeness also increases at each stage of the action. In the pre-action stage, the percentage of classical completeness was $38.46 \%$, the first cycle was $61.54 \%$, and the second cycle was $92.3 \%$.

Keywords: Inquiry, demonstration method, learning outcomes, science 


\section{PENDAHULUAN}

Pada hakekatnya kegiatan belajar mengajar adalah suatu proses interaksi atau hubungan timbal balik antara guru dan siswa dalam satuan pembelajaran (Gasong, 2018). Guru sebagai salah satu komponen dalam proses belajar menganjar merupakan pemegang peran yang sangat penting. Guru bukan hanya sekedar penyampai materi saja, tetapi lebih dari itu guru dapat dikatakan sebagai sentral pembelajaran (Minsih, 2018).

Sebagai pengatur sekaligus pelaku dalam proses belajar mengajar, gurulah yang mengarahkan bagaimana proses belajar mengajar itu dilaksanakan. Karena itu guru harus dapat membuat suatu pengajaran menjadi lebeh efektif juga menarik sehingga bahan pelajaran yang disampaikan akan membuat siswa merasa senang dan merasa perlu untuk mempelajari bahan pelajaran tersebut (Manizar, 2015).

Berhasilnya tujuan pembelajaran ditentukan oleh banyak faktor diantaranya adalah faktor guru dalam melaksanakan proses belajar mengajar, karena guru secara langsung dapat mempengaruhi, membina dan meningkatkan kecerdasan serta keterampilan siswa. Untuk mengatasi permasalahan di atas dan guna mencapai tujuan pendidikan secara maksimal, peran guru sangat penting dan diharapkan guru memiliki cara/model mengajar yang baik dan mampu memilih model pembelajaran yang tepat dan sesuai dengan konsep-konsep mata pelajaran yang akan disampaikan (Yuhana, 2019).

Tujuan pendidikan nasional tentunya sangat penting untuk bangsa Indonesia. Pendidikan nasional menurut Undang-undang No.20 tahun 2003 pasal 1 ayat 2 adalah pendidikan yang berdasarkan Pancasila dan Undang-undang Dasar Negara Republik Indonesia tahun 1945 yang berkarakter pada nilai-nilai agama, kebudayaan nasional Indonesia, dan tanggap terhadap tuntututan perubahan zaman (Sujana, 2019). Pendidikan nasional dilakukan sejak sekolah dasar sampai jenjang perguruan tinggi dan salah satu program pemerintah dalam mendukung program pendidikan wajib belajar 12 tahun, dimana pendidikan dimulai dari pendidikan sekolah dasar sampai pendidikan sekolah menengah atas (Lazwardi, 2017).

"Menurut Vito, dkk (2015), pendidikan adalah mengalihkan nilai-nilai, pengetahuan, pengalaman dan ketrampilan kepada generasi muda sebagai usaha generasi tua dalam menyiapkan fungsi hidup generasi selanjutnya, baik jasmani maupun rohani”. Menurut Noor (2018) pendidikan adalah kegiatan yang dilakukan manusia secara sadar dan terprogram guna membangun personalitas yang baik dan mengembangkan kemampuan atau bakat yang ada pada diri individu manusia agar mencapai tujuan atau target tertentu dalam menjalani hidup.

"Menurut Izza, dkk (2020), pendidikan merupakan bimbingan atau pertolongan yang diberikan oleh orang dewasa kepada perkembangan anak untuk mencapai kedewasaannya dengan tujuan agar anak cukup cakap melaksanakan tugas hidupnya sendiri tidak dengan bantuan orang lain". Oleh karena itu pendidikan sangat penting diberikan terhadap siswa dengan tujuan untuk mendidik dan mengajarkan siswa untuk mendapatkan ilmu pengetahuan serta perubahan yang positif untuk perkembangan dimasa mendatang.

"Menurut Rini, dkk, (2013), pendidikan merupakan proses mengubah tingkah laku anak didik agar menjadi manusia dewasa yang mampu hidup mandiri sebagai anggota masyarakat dalam lingkungan alam sekitar dimana individu itu berada". Dengan demikian, pendidikan bertujuan untuk mendidik dan mengajarkan siswa untuk mendapatkan ilmu pengetahuan dan perubahan yang positif. Pendidikan diharapkan dapat mengubah seseorang menjadi lebih baik. Dalam pelaksanaannya, pendidikan di sekolah dilakukan melalui proses pembelajaran antara guru dengan siswa.

Penggunaan metode ceramah yang tidak variatif sering dilaksanakan dalam setiap kegitan pembelajaran, sehingga aktivitas pembelajaran selalu didominasi oleh guru. Peserta didik menjadi pebelajar yang pasif, dan cepat merasa bosan dalam belajar (Rahayu, dkk, 2019). Hal ini dikarenakan pula langkanya penggunaan/ pemanfaatan alat-alat penunjang pembelajaran IPA. Peserta didik hanya menjadi pendengar, penulis ringkasan atau pencatat materi yang ada pada buku sumber. 


\section{Vol. 1 No. 3 Desember 2021 e-ISSN : 2797-3344 P-ISSN : 2797-3336}

Permasalahan tersebut disebabkan karena guru belum menggunakan metode pembelajaran inovatif yang mengaktifkan siswa, sehingga siswa kurang antusias dalam mengikuti pelajaran. Selain itu, aktivitas tanya jawab antara guru dan siswa sebagai suatu interaksi masih jarang dilakukan, sehingga siswa kurang optimis dalam menyampaikan pendapat. Guru juga belum menggunakan media dalam pembelajaran IPA, sehingga siswa kurang terfasilitasi dalam memahami materi yang sedang dipelajari.

Permasalahan mengenai rendahnya kualitas pembelajaran IPA di SD Negeri 3 Mamben Lauk merupakan masalah penting dan mendesak untuk segera dicari alternatif pemecahan masalahnya. Pada siswa kelas V SD Negeri 3 Mamben Lauk dengan data, dari 25 siswa terdapat 10 siswa $(40,00 \%)$ yang mendapatkan nilai diatas Kriteria Ketuntasan Minimal (KKM), sedangkan sisanya 15 siswa $(60,00 \%)$ mendapatkan nilai dibawah KKM, dengan KKM mata pelajaran IPA 65. Data tersebut menunjukkan perlu adanya penerapan metode dan media pembelajaran yang menarik agar dapat menambah antusias siswa untuk meningkatkan kualitas dan hasil belajar siswa pada mata pelajaran IPA di SD Negeri 3 Mamben Lauk.

Pembelajaran inovatif mengutamakan peran guru sebagai fasilitator, motivator, dan evaluator disamping informator. Selain itu, selama proses pembelajaran diharapkan dapat menambah antusias siswa dalam pembelajaran, serta meningkatkan semangat optimistis siswa dalam menyampaikan pendapat (Priansa, 2017). Salah satu metode pembelajaran yang dapat mengatasi permasalahan tersebut adalah melalui penerapan metode demonstrasi. Dengan menerapkan metode demonstrasi diharapkan dapat membuat siswa lebih aktif dalam pembelajaran (Nahdi, dkk, 2018).

"Menurut Arifuddin, dkk (2017), metode demostrasi menampilkan proses suatu benda maupun peristiwa yang dicontohkan oleh guru atau pengajar sehingga peserta didik dapat memahami dengan lebih mudah". Sedangkan penggunaan metode demonstrasi diharapkan dapat meningkatkan aktivitas siswa dalam proses belajar mengajar sehingga dalam proses belajar mengajar itu aktivitasnya tidak hanya didominasi oleh guru, dengan demikian siswa akan terlibat secara fisik, emosional dan intelektual.

Berdasarkan uraian di atas peneliti tertarik untuk mengadakan penelitian yang berjudul "Penerapan Metode Demonstrasi Untuk Meningkatkan Hasil Belajar IPA Pada Siswa Kelas V Semester Genap SD Negeri 3 Mamben Lauk Kecamatan Wanasaba Tahun Pelajaran 2020/2021".

\section{METODE PENELITIAN}

Jenis penelitian yang digunakan dalam penelitian ini adalah penelitian tindakan kelas (PTK) dan dilaksanakan pada semester genap tahun pelajaran 2020/2021. Penelitian tindakan kelas ini dilaksanakan di Kelas V SD Negeri 3 Mamben Lauk Kecamatan Wanasaba Kabupaten Lombok Timur yang merupakan tempat tugas peneliti.

Penelitian ini dilaksanakan dengan menggunakan dua siklus, dengan setiap siklusnya dilaksanakan proses pembelajaran minimal 2 kali pertemuan kemudian dilaksanakan evaluasi. Penelitian ini dilaksanakan selama kurang lebih tiga bulan, yaitu mulai Bulan Maret sampai dengan Mei 2021. Subyek penelitian adalah siswa kelas V SD Negeri 3 Mamben Lauk Kecamatan Wanasaba Kabupaten Lombok Timur Semester II tahun pelajaran 2020/2021 yang berjumlah 25 siswa dan terdiri atas 12 siswa laki-laki dan 13 siswa perempuan. Karena kondisi masa Covid-19 subyek penelitian yang diambil adalah 13 siswa dari 25 siswa yang terdiri atas 4 siswa laki-laki dan 9 siswa perempuan.

Penelitian ini menggunakan bentuk PTK Penelitian tindakan guru sebagai peneliti, yaitu Bentuk penelitian tindakan kelas yang memandang guru sebagai peneliti, yang memiliki ciri penting, yaitu sangat berperannya guru itu sendiri dalam proses PTK dalam bentuk ini, tujuan PTK ialah untuk meningkatkan praktek-praktek pembelajaran di kelas. Dalam kegiatan ini guru terlibat langsung secara penuh dalam proses: a) perencanaan tindakan (planning), b) pelaksanaan tindakan (acting), c) observasi (observation), d) Refleksi (Refleksion) 


\section{Vol. 1 No. 3 Desember 2021 e-ISSN : 2797-3344 P-ISSN : 2797-3336}

\section{HASIL DAN PEMBAHASAN}

\section{Siklus I}

Perencanaan, Pada tahap ini yang akan dilakukan adalah mempersiapkan semua kelengkapan penelitian baik berupa lembar observasi, instrument soal tes tulis, RPP dengan penerapan metode demonstrasi baik untuk setiap siklus sesuai kebutuhan. Tahap selanjutnya setelah perencanaan adalah membuat perangkat pembelajaran. Perangkat pembelajaran yang dibuat oleh peneliti meliputi Rencana Pelaksanaan Pembelajaran (RPP), lembar kerja siswa, rubik penilaian, lembar observasi pelaksanaan pembelajaran metode demonstrasi, serta soal evaluasi. Tahap selanjutnya adalah menentukan alat peraga dan media pembelajaran. Alat peraga mempunyai peranan yang penting untuk membantu siswa dalam menerima materi atau memperjelas konsep yang abstrak menjadi nyata. Penggunaan alat peraga dan media pembelajaran disesuaikan dengan kompetensi dasar serta indikator dalam setiap pertemuan. Lembar observasi disusun sebagai pedoman pengamatan aktivitas guru dan siswa dalam kegiatan pembelajaran menggunakan model pembelajaran metode demonstrasi. Lembar observasi guru berisi tentang pedoman observasi tehadap aktivitas guru dalam pembelajaran dengan menggunakan model pembelajaran metode demonstrasi.

Pelaksanaan Tindakan, Dalam Dalam tahap pelaksanaan tindakan dilaksanakan kegiatan pembelajaran sesuai dengan rencana pelaksanaan pembelajaran yang telah dibuat. Untuk dapat menyesuaikan rencana pelaksanaan pembelajaran dalam penyampaian materi, termasuk didalamnya pembelajaran dengan menggunakan metode demonstrasi untuk materi suhu dan kalor dilaksanakan 2 kali pertemuan untuk penyampaian materi dan 1 kali pertemuan untuk evaluasi. Proses pembelajaran siklus I dilaksanakan pada tanggal 5 April 2021 dan tanggal 10 April 2021 sedangkan evaluasi siklus II dilaksanakan pada tanggal 17 April 2021 dan tanggal 19 April 2021. Pelaksanaan siklus I ada dua pertemuan yaitu dari tanggal 05 April sampai dengan tanggal 10 April 2021. Dalam pelaksanaan pembelajaran pertemuan pertama pada tanggal 05 April 2021 kegiatan pembelajaran disesuaikan dengan RPP atau Skenario Pembelajaran Siklus I pertemuan I dengan materi pokok suhu dan kalor. Sedangkan untuk pelaksanaan pertemuan kedua pada tanggal 10 April 2021, merupakan lanjutan dari pelaksanaan pertemuan I dengan materi pokok perpindahan kalor di sekitar kita, pelaksanaan pembelajaran II ini disesuaikan dengan RPP atau Skenario Pembelajaran yang telah direncanakan. Dalam pelaksanaan pembelajaran pertemuan II ini merupakan tahap mempersentasikan dari masing-masing kelompok, mendiskusikan dalam intern kelompoknya tentang materi yang telah didiskusikan pada pertemuan I dan dalam pertemuan II, untuk mengukur tingkat penguasaan materi bagi siswa. Pada pelaksanaan siklus I ini dilakukan evaluasi siswa pada akhir pembelajaran pertemuan II, hal ini dilakukan untuk dapat mengetahui seberapa besar siswa memahami materi yang telah dipelajari.

Observasi dan Evaluasi, Hasil observasi diperoleh dari hasil pengamatan yang dilakukan oleh observer yang dilakukan pada setiap kali pertemuan pembelajaran dengan mengisi lembar observasi aktivitas siswa untuk merekam jalannya proses pembelajaran. Berdasarkan hasil observasi terhadap aktivitas siswa setelah dianalisa diperoleh data sebagai berikut:

Tabel 1 Hasil Observasi Aktivitas Siswa Pada Siklus I

\begin{tabular}{|c|c|c|c|c|c|c|c|c|c|}
\hline \multirow{2}{*}{ Pertemuan } & \multicolumn{6}{|c|}{ Jumlah skor yang tampak } & \multirow{2}{*}{$\begin{array}{c}\sum \text { Skor } \\
\text { aktivitas }\end{array}$} & \multirow{2}{*}{$\begin{array}{l}\text { Rata-rata } \\
\text { Aktivitas }\end{array}$} & \multirow{2}{*}{ Kategor } \\
\hline & 1 & 2 & 3 & 4 & 5 & 6 & & & \\
\hline Pertama & 2,7 & 1,7 & 2,0 & 2,0 & 1,7 & 1,3 & 11,4 & 1,9 & $\begin{array}{c}\text { Kurang } \\
\text { aktif }\end{array}$ \\
\hline Kedua & 3,3 & 2,7 & 2,3 & 2,3 & 2,3 & 2,3 & 14,9 & 2,5 & $\begin{array}{l}\text { Cukup } \\
\text { aktif }\end{array}$ \\
\hline
\end{tabular}

Dari tabel di atas dapat dilihat bahwa aktivitas belajar siswa pada siklus I pertemuan 1 diperoleh rata-rata sebesar 1,9 dengan kategori kurang aktif dan pertemuan 2 diperoleh ratarata sebesar 2,5 dengan kategori cukup aktif. Oleh karena itu maka aktivitas siswa pada siklus berikutnya masih perlu ditingkatkan. 
Vol. 1 No. 3 Desember 2021 e-ISSN : 2797-3344 P-ISSN : 2797-3336

Evaluasi Hasil Belajar, Data tentang evaluasi hasil belajar siswa pada siklus II berdasarkan hasil evaluasi setelah dianalisis diperoleh data sebagai berikut:

Tabel 2 Hasil Evaluasi Belajar Siswa Pada Siklus I

\begin{tabular}{|c|c|c|c|c|c|}
\hline No. & Nama Siswa & $\begin{array}{c}\mathbf{L} / \\
\mathbf{P}\end{array}$ & Skor & Nilai & $\begin{array}{c}\text { Tuntas(T)/Tidak } \\
\text { Tuntas(TT) } \\
\text { (KKM=65) }\end{array}$ \\
\hline 1. & Abdurrahman & $\mathrm{L}$ & 10 & 50 & Belum Tuntas \\
\hline 2. & Aura Wurwatussya'bani & $\mathrm{P}$ & 15 & 75 & Tuntas \\
\hline 3. & Ayudia Lestari & $\mathrm{P}$ & 13 & 65 & Tuntas \\
\hline 4. & Azizul Hafiz & $\mathrm{L}$ & 11 & 55 & Belum Tuntas \\
\hline 5. & Baiq Anita Safitri & $\mathrm{P}$ & 12 & 60 & Belum Tuntas \\
\hline 6. & Dedi Kurniawan & $\mathrm{L}$ & 11 & 55 & Belum Tuntas \\
\hline 7. & Dina Fatma Aulia & $\mathrm{P}$ & 15 & 75 & Tuntas \\
\hline 8. & Dinda Riana Sabila & $\mathrm{P}$ & 14 & 70 & Tuntas \\
\hline 9. & Faizul Umam & $\mathrm{L}$ & 11 & 55 & Belum Tuntas \\
\hline 10. & Halizatul Fitri & $\mathrm{P}$ & 14 & 70 & Tuntas \\
\hline 11. & Imelda Malia Zalianti & $\mathrm{P}$ & 16 & 80 & Tuntas \\
\hline 12. & Luluk Addanuri & $\mathrm{P}$ & 13 & 65 & Tuntas \\
\hline 13. & Nurdiana Khumaira & $\mathrm{P}$ & 17 & 85 & Tuntas \\
\hline \multicolumn{2}{|c|}{ Jumlah Nilai Seluruhnya } & \multicolumn{4}{|c|}{860} \\
\hline \multicolumn{2}{|c|}{ Nilai Rata-rata } & \multicolumn{4}{|c|}{66,15} \\
\hline \multicolumn{2}{|c|}{ Jumlah Siswa Yang Tuntas } & \multicolumn{4}{|c|}{8} \\
\hline \multicolumn{2}{|c|}{ Persentase Ketuntasan Klasikal } & \multicolumn{4}{|c|}{61,54} \\
\hline
\end{tabular}

Dari tabel di atas dapat dilihat bahwa ketuntasan belajar secara klasikal yang dicapai sebesar $61,54 \%$ dengan nilai rata-rata sebesar 66,15. Hasil ini belum mencapai ketuntasan belajar secara klasikal sehingga pembelajaran dilanjutkan ke siklus berikutnya.

Refleksi, Berdasarkan analisis hasil observasi pada siklus I, jumlah siswa yang tuntas secara klasikal sebesar $61,54 \%$ berarti belum memenuhi standar ketuntasan klasikal yang ditentukan. Oleh karena itu peneliti melanjutkan ke siklus II karena belum memenuhi standar sesuai perencanaan.

\section{Siklus II}

Perencanaan, Pembelajaran siklus II dilaksanakan dengan memperbaiki dan meningkatkan pembelajaran yang telah dilaksanakan pada siklus I. Usaha yang dilakukan peneliti dalam meningkatkan hasil belajar siswa pada siklus II dengan menggunakan metode demonstrasi adalah sebagai berikut: 1) guru berusaha untuk meningkatkan motivasi belajar siswa dengan memberikan nasihat, 2) guru mengubah kegiatan pembelajaran yang pada siklus I dilaksanakan di dalam kelas menjadi di luar kelas, 3) guru mengubah cara pemberian tugas menjadi kuis kelompok, 4) guru berusaha untuk menerangkan materi pembelajaran lebih jelas lagi untuk meningkatkan hasil belajar siswa.

Pelaksanaan Tindakan, Dalam tahap pelaksanaan tindakan dilaksanakan kegiatan pembelajaran sesuai dengan rencana pelaksanaan pembelajaran yang telah dibuat. Untuk dapat menyesuaikan rencana pelaksanaan pembelajaran dalam penyampaian materi, termasuk di dalamnya pembelajaran dengan menggunakan metode demostrasi untuk materi panas dan perpindahannya dilaksanakan dalam 3 kali pertemuan, dimana 2 kali pertemuan untuk penyampaian materi dan 1 kali pertemuan untuk evaluasi.

Observasi dan Evaluasi, Hasil observasi diperoleh dari hasil pengamatan yang dilakukan oleh observer yang dilakukan oleh rekan guru peneliti dengan mengisi lembar observasi aktivitas guru dan aktivitas siswa untuk merekam jalannya proses pembelajaran. Pada saat pembelajaran siklus II telah dilakukan perbaikan, dari analisis hasil observasi aktivitas siswa pada siklus II didapat bahwa aktivitas siswa tergolong aktif dalam setiap pertemuan. Hal 
Vol. 1 No. 3 Desember 2021 e-ISSN : 2797-3344 P-ISSN : 2797-3336

ini dapat dilihat pada tabel skor aktivitas siswa mengalami peningkatan dari pertemuan pertama ke pertemuan ke dua, seperti yang terlihat pada tabel di bawah ini.

Tabel 2 Hasil Observasi Aktivitas Siswa Pada Siklus II

\begin{tabular}{|c|c|c|c|c|c|c|c|c|c|}
\hline \multirow[b]{2}{*}{ Pertemuan } & \multicolumn{6}{|c|}{ Jumlah skor yang tampak } & \multirow{2}{*}{$\begin{array}{c}\Sigma \text { Skor } \\
\text { aktivitas }\end{array}$} & \multirow{2}{*}{$\begin{array}{l}\text { Rata-rata } \\
\text { Aktivitas }\end{array}$} & \multirow{2}{*}{ Kategori } \\
\hline & 1 & 2 & 3 & 4 & 5 & 6 & & & \\
\hline Pertama & 4,0 & 3,7 & 3,3 & 3,7 & 3,3 & 3,3 & 21,3 & 3,6 & Aktif \\
\hline Kedua & 4,3 & 4,0 & 4,3 & 4,0 & 4,3 & 4,3 & 25,2 & 4,2 & Aktif \\
\hline
\end{tabular}

Dari tabel diatas dilihat bahwa aktivitas siswa pada siklus II untuk pertemuan 1 adalah 3,6 dan pertemuan 2 adalah 4,2. Berdasarkan penggolongan aktivitas belajar siswa maka kategori aktivitas siswa pada siklus II adalah tergolong aktif.

Berdasarkan hasil evaluasi pada siklus II setelah dianalisis diperoleh data sebagai berikut:

Tabel 3 Hasil belajar yang diperoleh siswa pada siklus II

\begin{tabular}{|c|c|c|c|c|c|}
\hline No & Nama Siswa & $\mathbf{L} / \mathbf{P}$ & Skor & Nilai & $\begin{array}{c}\text { Tuntas/Tidak } \\
\text { Tuntas } \\
(\text { KKM=65) }\end{array}$ \\
\hline 1 & Abdurrahman & $\mathrm{L}$ & 14 & 70 & Tuntas \\
\hline 2 & Aura Wurwatussya'bani & $\mathrm{P}$ & 18 & 90 & Tuntas \\
\hline 3 & Ayudia Lestari & $\mathrm{P}$ & 15 & 75 & Tuntas \\
\hline 4 & Azizul Hafiz & $\mathrm{L}$ & 14 & 70 & Tuntas \\
\hline 5 & Baiq Anita Safitri & $\mathrm{P}$ & 15 & 75 & Tuntas \\
\hline 6 & Dedi Kurniawan & $\mathrm{L}$ & 14 & 70 & Tuntas \\
\hline 7 & Dina Fatma Aulia & $\mathrm{P}$ & 18 & 90 & Tuntas \\
\hline 8 & Dinda Riana Sabila & $\mathrm{P}$ & 17 & 85 & Tuntas \\
\hline 9 & Faizul Umam & $\mathrm{L}$ & 12 & 60 & Belum Tuntas \\
\hline 10 & Halizatul Fitri & $\mathrm{P}$ & 17 & 85 & Tuntas \\
\hline 11 & Imelda Malia Zalianti & $\mathrm{P}$ & 19 & 95 & Tuntas \\
\hline 12 & Luluk Addanuri & $\mathrm{P}$ & 16 & 80 & Tuntas \\
\hline 13 & Nurdiana Khumaira & $\mathrm{P}$ & 19 & 95 & Tuntas \\
\hline \multicolumn{4}{|c|}{ Jumlah } & 1.040 & \\
\hline \multicolumn{4}{|c|}{ Nilai Rata-rata } & 80 & \\
\hline \multirow{2}{*}{\multicolumn{4}{|c|}{$\begin{array}{l}\text { Jumlah Siswa yang Tuntas } \\
\text { Persentase Ketuntasan Klasikal }\end{array}$}} & 12 & \\
\hline & & & & $92,3 \%$ & \\
\hline
\end{tabular}

Hasil evaluasi yang diperoleh pada siklus II ini mencapai tingkat 92,3\% jadi sudah dapat dikatakan tuntas, untuk itu tidak perlu lagi diadakan pembelajaran pada siklus berikutnya dengan ketuntasan belajar yang sudah dicapai, dengan demikian pembelajaran dengan menerapkan Metode demonstrasi dikatakan dapat meningkatkan hasil belajar IPA pada materi panas dan perpindahannya.

Refleksi, Dari hasil observasi aktivitas siswa pada siklus II, kegiatan pembelajaran sudah dapat berjalan dengan baik, dimana hasil observasi aktivitas siswa dapat tergolong Aktif dilihat dari setiap kegiatan pembelajaran begitu juga aktivitas guru sudah tergolong Aktif. Dari hasil analisis terhadap hasil evaluasinya terjadi peningkatan rata-rata kelas maupun persentase ketuntasan secara klasikal sudah mencapai/melebihi 75\%. Oleh karena itu penelitian ini dihentikan sampai siklus II sesuai dengan perencanaan.

\section{Pembahasan}

Penelitian tindakan kelas ini dilaksanakan sebagai upaya untuk meningkatkan hasil belajar IPA pada siswa kelas V Semester genap dengan melaksanakan pembelajaran menggunakan metode demonstrasi di SD Negeri 3 Mamben Lauk Tahun Pembelajaran 2020/2021. Berdasarkan hasil analisis data pada tiap siklus, terlihat bahwa hasil dari siklus I ke 
Vol. 1 No. 3 Desember 2021 e-ISSN : 2797-3344 P-ISSN : 2797-3336

siklus II mengalami peningkatan. Pada pelaksanaan pembelajaran dan hasil analisis data siklus I, untuk aktivitas siswa diperoleh nilai rata-rata sebesar 66,15 dan aktivitas siswa pada siklus II diperoleh nilai rata-rata kelas sebesar 79,23, Pada pelaksanaan pembelajaran dan hasil analisis data siklus I.

Terkait dengan hasil ulangan pada siklus I dan II dapat dilihat rinciannya dibawah ini:

Tabel 4 Ringkasan Hasil Evaluasi Pada Siklus I

\begin{tabular}{llc}
\hline No & \multicolumn{1}{c}{ Uraian } & Hasil \\
1 & Nilai Terendah & 50 \\
2 & Nilai Tertinggi & 90 \\
3 & Rata-rata & 66,15 \\
4 & Jumlah siswa yang tuntas & 8 \\
5 & Jumlah siswa yang ikut tes & 13 \\
6 & Persentase Ketuntasan Klasikal & $61,54 \%$ \\
\hline
\end{tabular}

Tabel 5 Ringkasan Hasil Evaluasi Pada Siklus II

\begin{tabular}{llc}
\hline No & \multicolumn{1}{c}{ Uraian } & Hasil \\
1 & Skor Terendah & 60 \\
2 & Skor Tertinggi & 95 \\
3 & Rata-rata & 80 \\
4 & Jumlah siswa yang tuntas & 12 \\
5 & Jumlah siswa yang ikut tes & 13 \\
6 & Persentase Ketuntasan Klasikal & $92,3 \%$ \\
\hline
\end{tabular}

Setelah melihat kedua tabel hasil evaluasi dari siklus I dan II dimana nilai yang mereka peroleh sudah mencapai tingkat ketuntasan belajar. Dan melebihi tingkat ketuntasan belajar secara klasikal yaitu $75 \%$. Penelitian tindakan kelas ini dilaksanaan sebagai upaya untuk meningkatkan aktivitas dan hasil belajar IPA pada materi panas dan perpindahannya melalui penerapan metode demonstrasi.

\section{KESIMPULAN}

Berdasarkan hasil penelitian dan pembahasan diatas, dapat di simpulkan bahwa Penerapan metode demonstrasi dapat meningkatkan aktivitas dan hasil belajar siswa pada materi panas dan perpindahannya di SD Negeri 3 Mamben Lauk. Peningkatan tersebut dapat dilihat dari perolehan nilai skor aktivitas siswa, dan nilai rata-rata kelas serta tingkat ketuntasan secara klasikal pada tiap siklus mengalami peningkatan baik pada siklus I maupun siklus II.

Peningkatan hasil belajar siswa ditunjukkan dengan meningkatnya nilai rata-rata hasil belajar siswa pada setiap tindakan. Pada tahap pra siklus, nilai rata-rata kelas yang diperoleh adalah 58,84, sedangkan pada siklus I nilai rata-rata yang diperoleh adalah 66,15 dan Nilai ratarata siswa pada siklus II sebesar 79,23 ini membuktikan bahwa setiap siklus mengalami peningkatan pada setiah tahan tindakan. Persentase ketuntasan klasikal juga mengalami peningkatan pada setiap tahap tindakan. Pada tahap pra tindakan persentase ketuntasan klasikal sebesar $38,46 \%$, pada siklus I sebesar $61,54 \%$ dan pada siklus II sebesar 92,3\%.

Dari hasil penelitian dan pembahasan di atas dapatlah kami simpulkan Penerapan metode demonstrasi dapat meningkatkan hasil belajar IPA materi panas dan perpindahannya pada siswa kelas V SD Negeri 3 Mamben Lauk Tahun Pelajaran 2020/2021.

\section{DAFTAR PUSTAKA}

Arifuddin, A., \& Arrosyid, S. R. (2017). Pengaruh metode demonstrasi dengan alat peraga jembatan garis bilangan terhadap hasil belajar matematika materi bilangan bulat. $A l$ Ibtida: Jurnal Pendidikan Guru MI, 4(2), 165-178.

Gasong, D. (2018). Belajar dan pembelajaran. Deepublish. 
Vol. 1 No. 3 Desember 2021 e-ISSN : 2797-3344 P-ISSN : 2797-3336

Izza, A. Z., Falah, M., \& Susilawati, S. (2020). Studi literatur: Problematika evaluasi pembelajaran dalam mencapai tujuan pendidikan di era merdeka belajar. Konferensi Ilmiah Pendidikan 2020, 1(1), 10-15.

Lazwardi, D. (2017). Manajemen kurikulum sebagai pengembangan tujuan pendidikan. $A l$ Idarah: Jurnal Kependidikan Islam, 7(1), 119-125.

Manizar, E. (2015). Peran guru sebagai motivator dalam belajar. Tadrib, 1(2), 204-222.

Minsih, M. (2018). Peran guru dalam pengelolaan kelas. Profesi pendidikan dasar, 5(1), 20-27.

Nahdi, D. S., Yonanda, D. A., \& Agustin, N. F. (2018). Upaya Meningkatkan Pemahaman Konsep Siswa Melalui Penerapan Metode Demonstrasi Pada Mata Pelajaran IPA. Jurnal Cakrawala Pendas, 4(2).

Noor, T. (2018). rumusan tujuan pendidikan nasional pasal 3 undang-undang sistem pendidikan nasional No 20 Tahun 2003. Wahana Karya Ilmiah Pendidikan, 3(01).

Priansa, D. J. (2017). Pengembangan strategi dan model pembelajaran: inovatif, kreatif, dan prestatif dalam memahami peserta didik.

Rahayu, G. D. S., \& Firmansyah, D. (2019). Pengembangan pembelajaran inovatif berbasis pendampingan bagi guru sekolah dasar. Abdimas Siliwangi, 1(1), 17-25.

Rini, Y. S., \& Tari, J. P. S. (2013). Pendidikan: Hakekat, Tujuan, dan Proses. Jogyakarta: Pendidikan Dan Seni Universitas Negeri Jogyakarta.

Sujana, I. W. C. (2019). Fungsi dan tujuan pendidikan Indonesia. Adi Widya: Jurnal Pendidikan Dasar, 4(1), 29-39.

Vito, B., \& Krisnani, H. (2015). Kesenjangan pendidikan desa dan kota. Prosiding Penelitian dan Pengabdian kepada Masyarakat, 2(2).

Yuhana, A. N., \& Aminy, F. A. (2019). Optimalisasi peran guru pendidikan agama Islam sebagai konselor dalam mengatasi masalah belajar siswa. Jurnal Penelitian Pendidikan Islam, [SL], 7(1), 79-96. 